\title{
ASSESSMENT OF STIGMATIZATION AND DISCRIMINATION OF HIV-INFECTED PERSONS IN PROFESSIONAL MEDICAL EDUCATION INSTITUTIONS
}

\author{
Victoriya Datsyuk \\ Department of protection of public health \\ National Academy for public administration under the President of Ukraine \\ 20 Eugene Pottier str., Kyiv, Ukraine, 03057 \\ chikchik707@gmail.com
}

\begin{abstract}
The aim of the study. Finding out the attitude of the respondents to HIV-infected/AIDS patients, their awareness of the ways of HIV infection.

Methods. A survey of teachers and students of Kyiv City Medical College was conducted (educational institution of 1-2 levels of accreditation). The total number of students, who participated in the study, was 150 people aged 17 to 25 years. The survey involved 62 teachers aged 30 to 65 years. In order to find out the level of stigmatization of people living with HIV, a questionnaire has been developed that contains questions, related to various aspects of HIV infection and the lives of HIV-infected people.

Results. The study showed a high willingness to stigmatize and discriminate against people living with HIV/AIDS by teachers and medical school workers. The problem of reasonable stigma and discrimination against people living with HIV is the low level of knowledge about the epidemic. This is especially true for work. A tolerant attitude towards HIV-infected people from work and lectures at medical college is directly related to the awareness of these problems.

The high level of stigma and discrimination against HIV-infected students and teachers in medical schools is reflected in the willingness to refuse medical care to people living with HIV. The state's information policy in the field of combating stigma and discrimination against HIV-infected people is imperfect and insufficient.

Conclusions. The study shows the imperfection of the existing system of medical education in the field of upbringing of tolerant attitude to vulnerable groups, in particular to HIV-infected. In this area, the existing system of medical education needs to be improved and modernized. The aggravation of the problem of stigmatization and discrimination of HIV-infected people, the ineffectiveness of outdated methods requires the search for new approaches to its solution.
\end{abstract}

Keywords: stigmatization, discrimination, human immunodeficiency virus, health workers.

DOI: $10.21303 / 2504-5571.2020 .001411$

\section{Introduction}

The development of the HIV epidemic has led to the emergence and spread of the phenomenon of stigma and discrimination against people living with HIV [1]. The consequences of stigmatization and discrimination of HIV-infected people for society are difficult to overestimate. The spread of stigma, discrimination, and violations of the rights of HIV-infected people not only has a negative impact on the demographic, economic, and social situation [2]. Stigmatization and discrimination of HIV-infected people destroys moral and ethical traditions, hinders the development of society [3, 4]. Stigma and discrimination against HIV-infected people is recognized as one of the leading obstacles to the prevention, maintenance and treatment of HIV and AIDS [5]. This is leading to the spread of the HIV/AIDS epidemic.

Recently, people living with HIV have come to the attention of both government agencies and non-governmental organizations, as well as scientists. Research in the field of stigma, discrimination and tolerance of HIV-infected people is quite intensive. Thus, in 2012 in Ukraine, the Center for Social Expertise of the Institute of Sociology of the National Academy of Sciences of Ukraine conducted a research in Ukraine among health professionals on stigma and discrimination against HIV-infected people. The peculiarity of these studies was that surveys were conducted not only of medical workers (among them managers and responsible employees of medical institutions), but also of patients. These studies have shown that the practice of stigmatization and discrimination against HIV-infected people is still quite widespread among health professionals. One of the reasons for this is working conditions, which do not exclude the possibility of HIV infection 
during the provision of services, as well as the low level of knowledge of health workers about HIV prevention and mechanisms.

The issue of stigmatization of HIV-infected people by health professionals in his research was also raised by Shymkov E. V. [6]. He believes that the manifestations of stigmatization and discrimination against HIV-infected people in the medical environment are mainly characteristic of non-specialized health care workers. This is due, according to the researcher, to the lack of knowledge and lack of interaction between the medical and socio-psychological sectors of HIV support [6]. The phenomena of stigmatization of HIV-infected people in the medical environment in their studies are also described by Chernyavskaya O. A. and Ioannidi E. A. [7]. Researchers emphasize that it can affect the quality of medical services for HIV-infected people [7]. Based on his research, Belenska L. M. concludes that "medical workers, as well as the rest of society, have views that contribute to the formation of prejudice against HIV-infected and AIDS patients" [8].

Jessica Ogden and Laura Nyblade, 2005, conducted large-scale studies of HIV stigma and discrimination in Ethiopia, Tanzania, Zambia and Vietnam [9]. The researchers found that the stigma was primarily due to the fear of infection through regular household contact with people living with HIV. Moreover, fear of HIV infection is mainly related to misconceptions about HIV infection. This indicates a lack of information on the mechanisms of HIV infection. The authors identified, in addition to general, common to all countries, also regional manifestations and causes of stigmatization of HIV-infected people. According to the results of the research, the researchers identified four forms of stigma: physical, social, verbal and formally legalized [9]. Interesting data were obtained by Raifschneider T. Yu. [10]. According to her research, the manifestations of stigma against HIV-infected people depend on the multinational and multi-religious environment. Moreover, stigmatization of HIV-infected people is more pronounced in mono-ethnic and mono-confessional groups [10]. The research of Shumskaya N. O. and Madybayeva D. [11] was devoted to the issue of stigmatization, in particular, to HIV-infected people in the youth environment of Kyrgyzstan [11]. Researchers claim that young people have very low knowledge about HIV. This, according to researchers, is the main reason for the decline in tolerance to HIV-infected people among young people. Chernyavskaya O. A. and Ioannidi E. A. also believe that a lack of knowledge is one of the causes of the stigma of HIV-infected people. In their research, they found that there is an inverse correlation between the level of knowledge about HIV/AIDS and the severity of stigma and discrimination [7]. Data from domestic studies also indicate an extremely low level of awareness about HIV infection. Yes, a study conducted as part of the "Don't Give AIDS a Chance!" Campaign in 2013-2014, showed that only $55 \%$ of Ukrainians believe that they are very well or fairly well informed about HIV/AIDS. At the same time, the share of those, who thought they were poorly informed or not informed at all, was $37 \%$. At the same time, young people turned out to be more informed.

But, despite numerous studies, there are still many unexplored issues in this area. This is especially true of the stage of training of medical workers and their professional development.

The aim of the study is finding out the reasons for the formation of attitudes to HIV-infected/AIDS patients in professional medical education institutions.

\section{Materials and methods}

A survey of teachers and students of Kyiv City Medical College was conducted (educational institution of 1-2 levels of accreditation) in 2018. The total number of students, who participated in the study, was 150 people aged 17 to 25 years. They were dominated by women -130 people and 20 men. Among the surveyed students studying in the first year - 40 people, in the second year 20 people, in the third - 90 people.

The survey involved 62 teachers aged 30 to 65 years. 48 of them are women and 2 are men. The work experience of teachers ranged from 10 to 37 years. They were dominated by women 130 people and 20 men. Among the surveyed students studying in the first year -40 people, in the second year -20 people, in the third -90 people.

In order to find out the level of stigmatization of people living with HIV, a questionnaire has been developed that contains questions, related to various aspects of HIV infection and the lives 
of HIV-infected people. The questionnaire consists of the following questions, which had to be answered "yes" or "no" or "I do not know":

- Do you know that Ukraine ranks first among European countries in the spread of HIV/AIDS?

- Are there any HIV-infected people among your acquaintances, friends and relatives?

- Whether the state information policy on overcoming the HIV/AIDS epidemic in Ukraine is sufficient?

- Do you think that there are mass media (TV programs, newspaper columns, etc.) that provide regular and useful information on the problem of overcoming HIV/AIDS in Ukraine?

- How often do you access the Internet on HIV/AIDS?

- Are you aware of the existence of a state program to combat HIV/AIDS in Ukraine?

- Do you think that HIV-infected people deserve to be sick? diabetes?

- Do you think that people living with HIV deserve sympathy as patients with cancer,

- Do you think that health workers have the right to refuse medical care to HIV-infected people?

- Whether you have experienced discrimination and stigma (if you are HIV-positive)?

- Whether the state's efforts to combat discrimination and stigmatization of HIV-infected people are sufficient?

- Whether the efforts of civil society to combat discrimination and stigmatization of HIV-infected people are sufficient?

This questionnaire provides an opportunity to assess the state of the problem of HIV infection, attitudes towards people living with HIV, the opportunity to understand the willingness of society to be tolerant of people with HIV.

Methods of statistical analysis were used to solve the problems of the study. The criterion $\chi^{2}$ of Pirson was used to measure the nominal indicators. A critical level of statistical significance is 0.05 . The study described, analyzed and discussed the data obtained.

\section{Results}

The majority of respondents $(56.7 \%)$ showed a low level of awareness about the HIV epidemic in Ukraine. At the same time, among this category of respondents, there was mainly a lack of knowledge about the HIV epidemic in Ukraine (54.0\%). Only $43.3 \%$ of respondents answered positively about HIV/AIDS awareness in Ukraine. This indicates an extremely low level of HIV awareness among medical college students, future mid-level health workers.

At the same time, among the teachers of the medical college, the level of awareness about the HIV epidemic in Ukraine was higher than among the students, but still insufficient $(\mathrm{p}<0.05)$. Among teachers, $37.1 \%$ gave a negative answer and $4.8 \%$ showed a lack of knowledge in this area. Only $58.1 \%$ of respondents among teachers showed knowledge about the state of HIV in Ukraine. Insufficient awareness of respondents is also due to the fact that among their acquaintances, friends, relatives, they believe, there are no HIV-infected. Among the surveyed students, only $2.0 \%$ indicated that among their acquaintances, friends, relatives are HIV-infected.

The reason for low knowledge about the prevalence of the HIV/AIDS epidemic in Ukraine is the lack of information policy of the state in this area. Indeed, the research has shown that the majority of respondents - both students $(85.0 \%)$ and teachers $(92.0 \%)$ - thought so. According to only $10.0 \%$ of students and $8.0 \%$ of teachers, the state information policy in this area is sufficient.

The unsatisfactory level of information on HIV/AIDS is primarily due to the lack of media that would periodically cover this issue. This conclusion follows from the analysis of the answers. Indeed, most respondents either do not know (30.0\% of students and $20.0 \%$ of teachers) or believe that there are no $(65.0 \%$ of students and $87 \%$ of teachers, $\mathrm{p}<0.05)$ media that would provide regular and useful information on HIV/AIDS. At the same time, students of the medical college get basic information about HIV/AIDS on the Internet. This applies to $92.0 \%$ of surveyed students. At the same time, the number of teachers, who turn to the network for information on HIV/AIDS, is 
much smaller $-67.0 \%(\mathrm{p}<0.05)$. This may be due to age and mental differences between teachers and students.

According to the results of the survey, quite contradictory data were obtained regarding the treatment of HIV-infected people. As it turned out, attitudes towards HIV-infected/AIDS patients differed significantly between groups of students and teachers. The analysis of the answers showed that students are more tolerant of HIV-infected people than teachers $(p<0.05)$. Thus, $34.7 \%$ of students believed that HIV-infected people deserved to be ill and $10.0 \%$ did not know how to respond. At the same time, according to the majority of surveyed students (55.3\%), HIV-infected people deserve sympathy as well as patients with cancer and diabetes. $10.0 \%$ did not know how to answer this question and $34.7 \%$ of students answered negatively.

At the same time, the level of attitudes towards HIV-infected people among teachers differed significantly, compared to students. Among the teachers surveyed, $31 \%$ thought that HIV-infected people deserved to be sick and only $45 \%$ did not.

The number of teachers, who considered HIV-positive to be as sympathetic as those with cancer and diabetes, was significantly lower than among students $(\mathrm{p}<0.05)$. Only $48.4 \%$ of respondents among teachers answered positively to questions about sympathy for HIV-infected people. $38.7 \%$ of the surveyed teachers gave a negative answer to this question and $12.9 \%$ of teachers did not know how to answer.

The studies have shown that the vast majority of respondents, both students and teachers, believed that health workers have no right to refuse or provide medical care to HIV-infected people. At the same time, the structure of responses differed between groups of students and teachers $(\mathrm{p}<0.05)$. Thus, among students who believed that health workers had the right to refuse medical care, only $3.0 \%$ were living with HIV. However, $7 \%$ of students did not know how to answer this question.

Among teachers, the number of those, who believed that health workers had the right to refuse and not provide medical care to HIV-infected people, was $5 \%$. In addition, $15 \%$ of teachers did not know how to answer this question. Accordingly, according to $80 \%$ of teachers, health workers do not have the right to refuse and not provide medical care to HIV-infected people.

\section{Discussion}

Lack of knowledge about HIV is not unique to teachers of health care institutions. Literature data show that teachers in various educational institutions have insufficient knowledge about HIV. Thus, some researchers have noted a lack of awareness of school staff about HIV [12]. It is the lack of knowledge that leads to stigma and discrimination against people living with HIV. Thus, Shahgildyan V. I., Belyaeva V. V. emphasize that due to lack of knowledge about HIV, myths about HIV are widespread [13]. Lack of knowledge as a cause of stigmatization and discrimination was also found in the studies of Chernyavskaya O. A., Ioannidi O. O. [7].

Better awareness of teachers than students about the prevalence of HIV can be explained by a higher level of teacher education. Indeed, the literature suggests that higher education is associated with a higher level of HIV awareness [14].

Teachers (judging by the answers) did not have HIV-infected people among acquaintances, friends, relatives. It is unlikely that there were so few HIV-infected people among acquaintances, friends and relatives of the respondents. The answers of both students and teachers to this question most likely indicate the reluctance of HIV-infected people to disclose their status even to friends and relatives. This is most likely due to the fear of stigmatizing people living with HIV. It is also possible that the surveyed students and teachers have HIV-infected friends or relatives. But the respondents did not want to admit that they had HIV-infected acquaintances, friends or relatives, even in an anonymous survey. In this case, this can be explained by the reluctance to be even indirectly involved in HIV-infected people for fear of being stigmatized.

Zvonovskiy V. B. singles out the relationship of HIV-infected people with acquaintances, friends and relatives in a separate area [15]. The fact is that, on the one hand, acquaintances, friends and relatives often do not want to share the burden of stigma with the HIV-infected, and on the other hand, HIV-infected people are afraid of being stigmatized by friends and even relatives. Also, HIV-in- 
fected people do not report their status for fear of ruining relationships and families. The differences between teachers and students regarding the sources of information on HIV/AIDS may be explained by the fact that today's youth are the youth of the Internet age, where they get their information from.

People living with HIV/AIDS need proper medical care. Ensuring this complex process is the task of medical staff. Last but not least, the effectiveness of medical care for HIV-infected people depends on their interaction with health workers. But misconceptions about HIV infection, fear of infection, can cause a negative attitude of health workers towards HIV-infected people. Thus, according to Belenska L. M., $31.87 \pm 4.88 \%$ of outpatients and $4.92 \pm 2.77 \%$ of inpatient departments and $23.88 \pm 5.21 \%$ of paramedics and $13.78 \pm 2.46 \%$ of inpatient wards despise HIV-infected patients [8].

This undoubtedly disrupts the interaction between HIV-infected and health workers and, ultimately, creates stigma and discrimination against HIV-infected people in the medical field. The formation of a humanistic attitude towards HIV-infected people, a tolerant attitude towards them is carried out even after receiving professional medical education. Therefore, the purpose of the survey was also to assess the state of tolerance for HIV-infected/AIDS teachers and students of the medical college - future health workers.

The difference between the attitudes towards HIV-infected people between teachers and students can be explained by the age difference between them. The fact is that the life experience of teachers is much greater. Therefore, perhaps they are not so categorical in their thoughts and their attitude to complex problems. At the same time, for young people the attitude to an issue is usually determined by only two colors - white and black. That is why the number of students, who did not decide on the answer to this question, was not significant, compared to teachers.

Negative attitudes towards HIV-infected people on the part of both students and teachers reflect the negative attitudes towards HIV-infected people typical of ordinary citizens [16]. From the point of view of ordinary citizens, HIV-infected people are "to blame" because they behaved unworthily, so they deserve this disease and do not deserve sympathy. This is usually one of the reasons for the stigmatization of HIV-infected people. According to Zvonovskiy V. B., unworthy, deviant lifestyle, this is one of the so-called "defects" of HIV-infected in terms of "normal" citizen [15].

Blaming HIV-infected people and denying them compassion and support is common in many countries. Thus, according to Jessica Ogden and Laura Nyblade, 2005, in African countries, accusations of HIV infection are a leading cause of stigma [9]. Moreover, according to the researchers, stigmatization is not only of HIV-infected, but also of their loved ones, family members, those, who live with them [9]. In African countries, where the research of stigmatization and discrimination of HIV-infected people was conducted, it was perceived as a punishment for moral offenses, unworthy behavior [9]. In T. Raifschneider's research, the majority of respondents also associated HIV infection with deviant behavior [10].

The data show that young people are more tolerant of HIV-infected people than older people. Moreover, this is despite the fact that teachers are more literate and, consequently, more aware of HIV than students. Perhaps this is due to the fact that the formation of modern youth takes place in an era of more open, democratic and tolerant world. For the youth of the XXI century, democratic values, human rights are not something strange, incomprehensible, alien.

Young people, born at the end of the XX and the beginning of the XXI century, are a part of the modern global world, which is dominated by diversity, multiculturalism, openness, when borders are open, when you wake up in one country, have lunch in another, fall asleep in the third. That is why for modern Ukrainian youth democratic values, human rights, tolerance, respect for others are natural and familiar. At that time, the mentality of most teachers - older people - was formed in Soviet times, in a totalitarian state, when intolerance to everything else flourished.

Thus, a tolerant attitude towards HIV-infected people may depend not only and not so much on the level of knowledge about HIV, but also on the general atmosphere of tolerance and respect in society. Indeed, it is a well-known fact that in developed countries, where democratic traditions have existed for a long time, where human rights are a priority, where civil society is active and independent media are active, tolerance and respect are quite high.

Other researchers agree with the greater tolerance of young people to HIV-infected people. Thus, according to Petrova O. O., Krasnikova T. V., the youth environment is more tolerant 
of HIV-infected and more informed, while the main source of stigmatization and discrimination against HIV-infected are people of older age [17]. A Ukrainian researcher Kalchenko A. M. agrees that, in general, older people support a high level of stigma and discrimination against HIV-infected people [18].

The opinion of those respondents, who believed that health workers have the right to refuse medical care to HIV-infected people, may be explained, on the one hand, by the fear of HIV infection in the provision of medical services, and on the other hand by insufficient preventive and protective measures in medical care institutions.

At the same time, the research shows that modern professional medical education in Ukraine does not provide the necessary and satisfactory information on the state of HIV infection. One of the reasons for this is the lack of knowledge of teachers about HIV. The unsatisfactory level of students' knowledge can also be explained by the fact that there are no thematic classes on stigmatization, discrimination and tolerance in the curricula. Many teachers and students get information in the media and on the Internet. But the quantity and quality of information content in the media obviously does not meet the needs of society. Evidence of this is the data, obtained from the survey.

Tolerance of HIV-infected students and teachers of the medical college is directly related to awareness of this problem. Unsatisfactory knowledge of students and teachers about the state of HIV infection in Ukraine, on the one hand, indicates the need to optimize and modernize the system of professional medical education. The problem of stigma and discrimination against people living with HIV requires the introduction of broad educational programs and training not only among the population, but also in medical schools.

Ensuring this can increase the awareness of teachers and future health professionals about HIV. This will have a positive effect on overcoming the stigma and discrimination of HIV-infected people, will promote the adaptation and integration of people living with HIV into society.

On the other hand, the lack of information in the field of HIV needs to improve the information policy of the state in this area. It is the lack of knowledge about the problem that leads to stigmatization and discrimination against HIV-infected people. Indeed, both among students and teachers of the medical college, the level of attitudes towards HIV-infected people turned out to be quite negative. Naturally, the level of tolerance for HIV-infected people among the respondents was also low. Moreover, a lower level of tolerance and attitude towards HIV-infected people was found among teachers.

The research revealed areas of work on the formation of a tolerant attitude to HIV-infected/AIDS patients in professional medical education institutions. This is the prospect of further research.

Study limitations. The study was limited to surveys of health professionals, namely medical college students and their teachers.

Research prospects. Prospects for further research are to conduct similar social surveys in the coming years and to monitor changes in attitudes towards HIV-infected/AIDS people among health workers and teachers.

\section{Conclusions}

1. A high readiness for stigmatization and discrimination on the part of teachers and students of medical schools - future medical workers was revealed.

2. The leading cause of stigma and discrimination against people living with HIV is the low level of knowledge about this epidemic. This is especially true for students. Tolerance of HIVinfected students and teachers of the medical college is directly related to awareness of this problem.

3. The high level of stigma and discrimination against HIV-infected students and teachers in medical schools is reflected in the willingness to refuse medical care to people living with HIV.

4. The research shows the imperfection of the existing system of medical education in the field of upbringing of tolerant attitude to vulnerable groups, in particular, HIV-infected. The existing system of medical education needs to be improved and modernized in this area. They need to review and improve the curriculum in medical educational institutions on the problem of stigmatization and discrimination of HIV-infected people. 
5. The state's information policy in the field of combating stigma and discrimination against HIV-infected people is imperfect and insufficient. The aggravation of the problem of stigmatization and discrimination of HIV-infected people, the ineffectiveness of outdated methods, requires the search for new approaches to its solution.

\section{Conflict of interests}

The authors declare that they have no conflicts of interest.

\section{References}

[1] Butt, G., Paterson, B. L., McGuinness, L. K. (2007). Living With the Stigma of Hepatitis C. Western Journal of Nursing Research, 30 (2), 204-221. doi: http://doi.org/10.1177/0193945907302771

[2] Unnikrishnan, B., Mithra, P., Rekha, T., Reshmi, B. (2010). Awareness and attitude of the general public toward HIV/AIDS in coastal Karnataka. Indian Journal of Community Medicine, 35 (1), 142-146. doi: http://doi.org/10.4103/0970-0218.62580

[3] Chapman, E. (2000). Conceptualisation of the body for people living with HIV: issues of touch and contamination. Sociology of Health \& Illness, 22 (6), 840-857. doi: http://doi.org/10.1111/1467-9566.00233

[4] Chirwa, M. L., Greeff, M., Kohi, T. W., Naidoo, J. R., Makoae, L. N., Dlamini, P. S. et. al. (2009). HIV Stigma and Nurse Job Satisfaction in Five African Countries. Journal of the Association of Nurses in AIDS Care, 20 (1), 14-21. doi: http://doi.org/ 10.1016/j.jana.2008.10.001

[5] UNAIDS. Confronting discrimination (2017). Available at: http://www.unaids.org/en/resources/documents/2017/confronting-discrimination

[6] Shimkov, E. V. (2011). VICH infektsiia kak kompleksnaia problema meditsinskogo i sotsialno-psikhologicheskogo soprovozhdeniia. Uroven zhizni naseleniia regionov Rossii, 1, 59-64.

[7] Cherniavskaia, O. A., Ioannidi, E. A. (2014). Nekotorye aspekty problemy stigmatizatsii i diskriminatsii liudei, zhivuschikh s VICH/SPIDom. Sotsiologiia meditsiny, 2, 46-48.

[8] Bielienska, L. M. (2006). Udoskonalennia orhanizatsii medychnoi dopomohy VIL-infikovanym i khvorym na SNID ta obgruntuvannia profilaktychnykh zakhodiv. Kyiv: Natsionalna medychna akademiia pisliadyplomnoi osvity im. P. L. Shupyka, 322.

[9] Ogden, J., Nyblade, L. (2005). Common at its Core: HIV-Related Stigma Across Contexts. The International Center for Research on Women, 274, 16.

[10] Raifshnaider, T. Iu. (2015). Izuchenie proksimalnosti k detiam s VICH u subektov profilakticheskogo obrazovaniia. Mir psikhologii, 1, 190-195.

[11] Shumskaia, N. O., Madibaeva, D. (2015). Otsenka informirovannosti molodezhi o sotsialno-znachimykh zabolevaniiam (VICH, IPPP i tuberkulez), reproduktivnom zdorove i posledstviiakh riskovannogo povedenii ia v krupnykh gorodakh Kyrgyzstana. Vestnik KGMA im. I. K. Akhunbaeva, 2 (1), 45-51.

[12] Holzemer, W. L., Uys, L. R., Chirwa, M. L., Greeff, M., Makoae, L. N., Kohi, T. W. et. al. (2007). Validation of the HIV/AIDS Stigma Instrument - PLWA (HASI-P). AIDS Care, 19 (8), 1002-1012. doi: http://doi.org/10.1080/09540120701245999

[13] Shakhgildian, V. I., Beliaeva, V. V. (2007). Palliativnaia pomosch pri VICH/SPIDe. Rukovodstvo po okazaniiu palliativnoi pomoschi liudiam, zhivuschim s VICH. Moscow: ROO «SPID-infosviaz», 170.

[14] Bemelmans, M., van den Akker, T., Pasulani, O., Tayub, N., Hermann, K., Mwagomba, B. et. al. (2011). Keeping health staff healthy: evaluation of a workplace initiative to reduce morbidity and mortality from HIV/AIDS in Malawi. Journal of the International AIDS Society, 14 (1), 1. doi: http://doi.org/10.1186/1758-2652-14-1

[15] Zvonovskii, V. B. (2008). VICH i stigma. Zhurnal issledovanii sotsialnoi politiki, 6 (4), 505-522.

[16] Imam, M., Karim, M., Ferdous, C., Akhter, S. (1970). Health related quality of life among the people living with HIV. Bangladesh Medical Research Council Bulletin, 37 (1), 1-6. doi: http://doi.org/10.3329/bmrcb.v37i1.7791

[17] Petrova, E. A., Krasnikova, T. V. (2011). Issledovanie predstavlenii o VICH-infitsirovannykh i stigmy, sviazannoi s VICH/ SPIDom. Uroven zhizni naseleniia Regionov Rossii,» 1, 25-33.

[18] Kalchenko, A. M. (2013). Otsinka rivniv styhmatyzatsii ta dyskryminatsii VIL-infikovanykh ta khvorykh na SNID sered pratsivnykiv likuvalno-profilaktychnykh ustanov Ukrainy. Zbirnyk naukovykh prats NMAPO imeni P.L. Shupyka, 22 (4), 129-135. 